\title{
STUDI IN SILICO KOMPLEKS LIGAND-RESEPTOR EUGENOL DAUN BASIL (Ocimum basilicum L.) DENGAN RESEPTOR HER2 PADA NON-SMALL CELL LUNG CANCER (NSCLC) DENGAN KONTROL GEFITINIB
}

\author{
STUDY IN SILICO LIGAND-EUGENOL RECEPTOR COMPOUND OF BASIL LEAF \\ (Ocimum basilicum L.) WITH HER2 RECEPTOR ON NON-SMALL CELL LUNG CANCER \\ (NSCLC) WITH GEFITINIB CONTROL
}

\author{
MARTINA KURNIA ROHMAH ${ }^{\bullet}$ \\ ${ }^{1}$ STIKes Rumah Sakit Anwar Medika
}

\begin{abstract}
Abstrak: Non-Small Cell Lung Cancer (NSCLC) merupakan jenis kanker paru dengan prevalensi 85\% dari total penyakit paru. Senyawa 4-(methylnitrosamino)-1-(3pyridyl)-1-butanone (NNK) pada rokok dapat mengaktifkan transduksi sinyal Akt dan meningkatkan kemampuan proliferasi dan siklus sel pada kanker ini. Her2 merupakan salah satu reseptor yang aktif mentransduksi sinyal Akt. Her2 mengalami overekspresi dan meningkatkan sinyal pertumbuhan pada NSCLC. Her2 banyak digunakan sebagai salah satu target terapi antikanker. Melalui penghambatan reseptor Her2 diharapkan dapat menurunkan proliferasi dan siklus sel NSCLC. Gefitinib merupakan salah satu obat yang banyak digunakan pada NSCLC dengan aktivitas menghambat reseptor Her2 dan tyrosine kinase. Namun saat ini, NSCLC dengan mutasi pada onkogen K-ras dilaporkan memiliki potensi untuk resisten terhadap gefitinib. Eugenol dari daun basil memiliki kemampuan menurunkan proliferasi sel NSCLC, namun mekanisme molekularnya belum banyak diketahui. Melalui studi in silico ini kami bertujuan untuk mempelajari ada tidaknya interaksi antara kompleks ligand reseptor eugenol ekstrak daun basil dengan reseptor Her2. Hasil studi in silico dengan docking diketahui bahwa eugenol dapat berikatan kuat dengan reseptor Her2 melalui interaksi permukaan sebesar 411.564 dan besar energi ikatan bebas yang kecil yaitu -4.16 $\mathrm{kcal} / \mathrm{mol}$ serta memiliki aktivitas penghambatan terhadap reseptor Her-2 yang mengalami overespresi pada NSCLC dengan nilai Ki (konstanta inhibisi) sebesar $895.67 \mu \mathrm{M}$.
\end{abstract}

Kata Kunci: eugenol, gefitinib, Her-2, NSCLC

\begin{abstract}
Non-Small Cell Lung Cancer (NSCLC) accounts for 85\% of all lung cancer cases. The 4(methylnitrosamino)-1-(3pyridyl)-1-butanone (NNK) in cigarette activates Akt transduction signal and increase proliferation and cell cycle in this cancer. Receptor Her-2 can transduce this Akt pathway. This receptor is overexpressed and increases growth signal in NSCLC. Her-2 is widely use as the target of anticancer therapy. Inhibition of Her-2 decreases proliferation and cell cycles of NSCLC. In this cancer, gefitinib inhibits this receptor and tyrosine kinase activity. However, NSCLC with K-ras oncogene mutation resist to gefitinib. Eugenol from basil leaves has known can decrease NSCLC cell proliferation. This study aim was investigating the molecular interaction and inhibitory activity of eugenol in Her-2 receptor. This study shown that eugenol has highly interaction and inhibitory activity in Her-2 receptor. It was proven by high interaction surface (411.564), low free energy binding $(-4.16 \mathrm{kcal} / \mathrm{mol})$, and low inhibition constant value $(895.67 \mu \mathrm{M}$. It was indicated that we can use eugenol as alternative therapy in NSCLC by Her- 2 inhibition activity.
\end{abstract}

Key words: eugenol, gefitinib, Her-2, NSCLC

\section{PENDAHULUAN}

Non-Small Cell Lung Cancer (NSCLC) merupakan salah satu jenis kanker paru dengan prevalensi $80-85 \%$ dari seluruh kasus kanker paru dengan $90 \%$ dan $80 \%$ berturut-turut pada laki-laki dan perempuan disebabkan oleh merokok (Addario et al., 2010). Faktor resiko dari kasus kanker paru ini berkaitan dengan konsumsi alkohol, lingkungan (perokok pasif), makanan dan aktivitas fisik. Ada dua klasifikasi utama NSCLC yaitu preinvasive lesion dan invasive malignant lesion. Preinvasive lesion terdiri dari squamous dysplasia, adenomotous hyperplasia dan diffuse idiophatic pulmonary neuroendocrine cell hyperplasia. Invasive

•email korespondensi: martina.kurniarohmah@gmail.com 
malignant lesion terdiri dari squamous cell carcinoma, small cell carcinoma, adenocarcinoma, large cell carcinoma, adenossquoamous carcinoma, carcinoma dengan pleomorphic, dan carcinoid tumor (Devita et al., 2011).

Efek rokok pada sel epitel respiratori terkait dengan beberapa senyawa organik dan anorganik yang bersifat karsinogenik di antaranya adalah 4-(methylnitrosamino)-1(3pyridyl)-1-butanone (NNK), nicotine, benzo(a)pyrene, cadmium, formaldehyde, dan ethylcarbamate. NNK menginduksi ekspresi reseptor Insulin Growth Factor tipe 1 (IGF-1) dan mengaktifkan sinyal Akt pada sel epithelial respiratori. NNK juga mengaktifkan $k$-ras dan meningkatkan regulasi DNA methyltransferase pada sel pneumoni. Polyaromatic hydrocarbon $(\mathrm{PAH})$ dari rokok dapat menginduksi mutasi sejumlah gen yaitu p53, RASSF 1A, dan FHIT sehingga dapat mengganggu regulasi pada siklus sel, DNA repair dan apoptosis. Tidak hanya NNK dan PAK saja, sejumlah logam yang berikatan dengan nikotin seperti nikel, arsenik dan kromium diasosiakan dengan munculnya transformasi neoplastik. Nikel dan arsenik diasosiasikan dengan perubahan epigenetik yang berkaitan dengan kanker yang mana nikotin sendiri mampu mengaktifkan jalur sinyal Akt, ERK, dan PKC yang penting pada siklus sel dan proliferasi. Dengan demikian logam tersebut diperkirakan dapat menimbulkan terjadinya perubahan epigenetik yang berkaitan dengan ketiga sinyal tersebut. Nikotin juga dapat mengaktifkan Raf-1 kinase dan c-fos yang menyebabkan terjadinya progresi proliferasi dan siklus sel pada sel epithelial respiratori (Devita et al., 2011).

Epidermal Growth Factor Receptor (EGFR) merupakan salah satu reseptor yang diekspresikan sekitar 40-80\% pada NSCLC (Devita et al., 2011). EGFR merupakan reseptor transmembran glikoprotein dengan berat molekul $170 \mathrm{kDa}$ yang dikode oleh protoonkogen Her-1 dan berlokasi pada kromosom 7p12. Fungsi EGFR yaitu mengaktifkan suatu domain tyrosine kinase yang meregulasi sejumlah fungsi seluler seperti pertumbuhan sel, differensiasi, ekspresi gen dan perkembangan. EGFR hadir pada jaringan normal dan juga diekspresikan pada sejumlah tumor solid (Baselga, 2002). Ada 4 protein dari fanili $E G F R$ yaitu: 1) $E G F R / H e r-1 / e r b B 1,2)$ Her-2/neu, 3) Her-3/erbB3, dan Her-4/erbB4. Keempat $E G F R$ tersebut dapat mengoperasikan transduksi sinyal cascade melalui Phosphoinositide-3-kinase (PI3K)/AKT dan Extracellular Signal-Regulated Kinase (ERK)1/2. Kedua jalur sinyal tersebut berperan penting di dalam memodulasi proliferasi, migrasi, adesi sel, differensiasi, angiogenesis dan apoptosis sel kanker (Prenzel et al., 2001). Overekspresi EGFR sering diasosiasikan dengan perkembangan stadium kanker dan metastasis dari sejumlah kanker yaitu NSCLC, kanker payudara, kanker serviks, kepala dan leher, kanker esophagus serta kanker kolorektal (Hirata et al., 2005). Selama decade terakhir, family EGFR banyak menjadi target dalam perkembangan obat antikanker dalam bentuk senyawa berupa molekul kecil dan antibody monoklonal (Baselga et al., 2002).

Gefitinib (Iressa, ZD1839) merupakan obat yang dikonsumsi secara oral dan memiliki aktivitas dalam menghambat EGFR tyrosine kinase sehingga dapat memblok transduksi sinyal dalam perkembangan kanker (Albanell $e t$ al., 2002). Studi klinis membuktikan bahwa gefitinib dapat digunakan sebagai monoterapi pada pases NSCLC di beberapa negara di Australia, Jepang dan USA (Fukuoka et al., 2003). Suatu penelitian terbaru menunjukkan bahwa pasien dengan NSCLC memiliki mutasi yang spesifi pada gen EGFR yang secara klinis mampu merespon gefitinib (Lynch et al., 2004). Mutasi EGFR dapat meningkatkan sinyal dari faktor pertumbuhan. Penelitian lain menyebutkan bahwa pemberian gefinitib pada pasien NSCLC dengan mutasi EGFR berkaitan dengan sinyal Akt dan ERK1/2 (Ono et al., 2004). Di sisi lain, Her2 yang merupakan salah satu family EGFR memiliki ekspresi yang tinggi (over ekspresi) pada sejumlah kanker. Her2/erbB2 merupakan protein transmembran tyrosine kinase dengan berat molekul sebesar $185 \mathrm{kDa}$. Peningkatan level ekspresi Her2 berimplikasi terhadap peningkatan proliferasi pada beberapa kanker seperti NSCLC (Agus et $a l ., 2000)$. kanker payudara, kanker ovary dan kanker perut. Pada family $E G F R$, gefitini mampu mengambat fosforilasi EGFR/Her-1 pada kadar konsentrasi inhibisi $\left(\mathrm{IC}_{50}\right)$ sebesar 27-33 nmol/L, Her2 3.7 Amol/L (Woodburn, 1999).

Saat ini obat herbal banyak dipercaya untuk mengobati berbagai jenis penyakit termasuk kanker karena sifatnya yang aman dan memiliki kasiat yang tidak kalah dibandingkan dengan obat kimia. Beberapa jenis tanaman yang telah banyak diteliti dan 
memiliki aktivitas antikanker antara lain kunyit, jahe, bawang putih, ginseng, jinten hitam, kedelai, anggur, kayu manis, dan beberapa tanaman herbal dari Cina yang disebut Traditional Chinese Medicine (TCM). Daun basil (Ocimum basilicum L.) merupakan salah satu tanaman herbal yang juga mulai banyak diteliti kandungan dan potensinya sebagai obat antikanker.

Eugenol merupakan salah satu senyawa dari kelompok phenylpropene dengan rumos molekul $\mathrm{C}_{10} \mathrm{H}_{12} \mathrm{O}_{2}$. Eugenol disintesis dari Lphenylalanine menjadi conyferyl alcohol, coniferyl acetate dan kemudian menjadi eugenol melalui proses eugenol synthase (EGS) (Louie et al., 2007). Eugenol berwarna kuning bening hingga kuning pucat dan kental seperti minyak. Eugenol merupakan salah satu essential oil yang terdapat pada daun basil dengan kandungan $0.896 \mathrm{mg} / \mathrm{g}$ (Lee et al., 2004) atau $10 \%$ dari total kandungan senyawa pada daun basil (Keitha et al., 2004). Eugenol telah diteliti memiliki aktivitas antikanker di antaranya bersifat pro-apoptotik pada kanker payudara dengan menurunkan regulasi E2F1/survivin (Al-sharif et al., 2013) dan kanker melanoma (Ghosh et al., 2005) dan pada kanker kolon, eugenol memiliki sifat antiproliferatif, pro-apoptosis melalui pembentukan ROS dan aktivasi p53, PARP dan caspase 3 dan menurunkan level MMP yang penting bagi invasi jaringan (Jaganathan et al., 2011). Pada NSCLC, eugenol $(211 \mu \mathrm{M})$ bersama eucalyptol $(2.95 \mathrm{mM})$, terpinen-4-ol $(683 \mu \mathrm{M})$, dan camphor $(29.65 \mu \mathrm{M})$ mampu memberikan efek sitotoksisitas terhadap NSCLC cell line H1299 (Ozkan dan Erdogan, 2012). Meskipun eugenol telah terbukti dapat menurunkan prognosivitas kanker namun mekanisme molekularnya belum banyak diketahui.

Suatu usaha dalam mengembangkan kandidat obat baru dapat digunakan dengan studi awal berupa studi in silico yang nantinya akan dilanjutkan dengan studi pada skala laboratorium. Studi in silico ini dilakukan dengan tujuan untuk mempelajari interaksi antara kompleks ligand reseptor eugenol dari ekstrak daun basil dengan reseptor Her-2 terutama pada NSCLC dengan menggunakan kontrol berupa obat gefitinib yang sudah banyak digunakan untuk kasus kanker NSCLC dengan overekspresi reseptor Her-2. Her-2 memiliki ekspresi yang tinggi pada $N S C L C$ dan merupakan salah satu reseptor yang mampu mentransduksi sinyal pertumbuhan melalui Akt dan ERK 1/2. Suatu obat gefitinib yang merupakan tyrosine kinase inhibitor dan telah terbukti dapat menghambat reseptor Her-2 digunakan sebagai pembanding untuk mengetahui aktivitas eugenol terhadap reseptor Her-2. Namun belakangan, obat gefitinib ini dapat menimbulkan resistensi pada kanker NSCLC yang mengalami mutasi pada onkogen Kras (Chen et al., 2013). Untuk itu perlu adanya zat aktif alternatif pengganti gefitinib yang mampu berikatan dan mempunyai aktivitas penghambatan pada reseptor Her-2 sebagai alternatif obat antikanker.

\section{METODE PENELITIAN}

\section{Preparasi Ligand dan Reseptor}

Ligand utama digunakan yaitu eugenol dengan ligand pembanding (kontrol) yaitu gefinitib. Sedangkan reseptor yang digunakan yaitu Her2 (PDB ID: 1n8z). Data ini diambil dari RCSB PDB (Protein Data Bank). Berikut ini merupakan gambar molekul 3 dimensi dari ketiga protein tersebut:

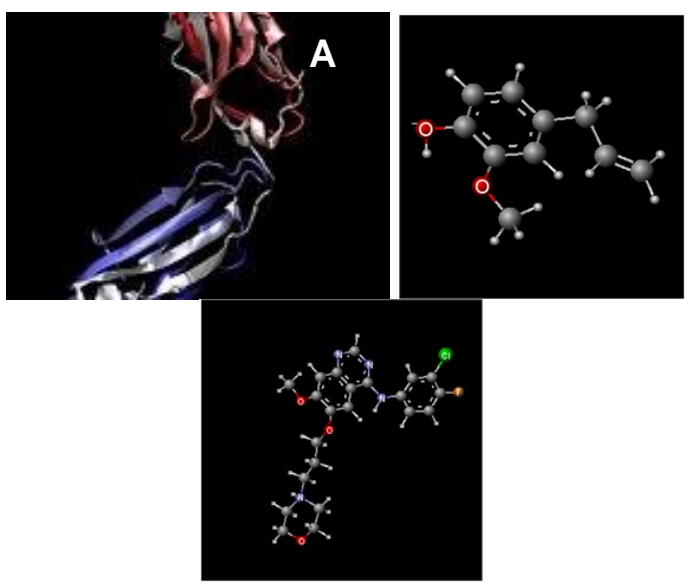

Gambar 1. Gambar Molekul Tiga Dimensi: A. Reseptor Her2, B. Eugenol (1,3,4 Eugenol), C. Gefitinib (Protein Data Bank A) ID. 1n8z; B) ID. 2QW8; C) ID. 4KWQ)

\section{Molekular Docking}

Docking merupakan salah satu studi in silico untuk mengetahui interaksi antara protein dengan protein dan dalam hal ini adalah ligand dengan reseptor. Proses docking yang dilakukan pada studi ini menggunakan web server bernama docking server. Untuk melakukan docking pada docking server, langkah pertama yaitu memasukkan (input) 
data protein pada "my protein" (sebagai reseptor) dan ligand pada "my ligand" menggunakan satu dari dua cara yaitu upload file PDB dari protein yang sudah kita miliki atau dengan mengakses RCSB yang sudah terkoneksi dari docking server. Setelah proses ini berhasil (done) maka proses docking dapat dilakukan. Hasil (output) dari proses docking menggunakan docking server adalah interaksi antar kompleks ligand-reseptor, energi ikatan bebas, dan konstanta inhibisi.

\section{HASIL PENELITIAN}

Hasil docking molekular ligand dan reseptor diwujudkan dengan adanya kompleks interaksi molekul keduanya. Berdasarkan ada tidaknya kompleks interaksi molekul kedua senyawa tersebut dapat dilihat adakah suatu ligand dapat berikatan dengan reseptor target. Berikut merupakan gambar 3D hasil docking menggunakan docking server.
A

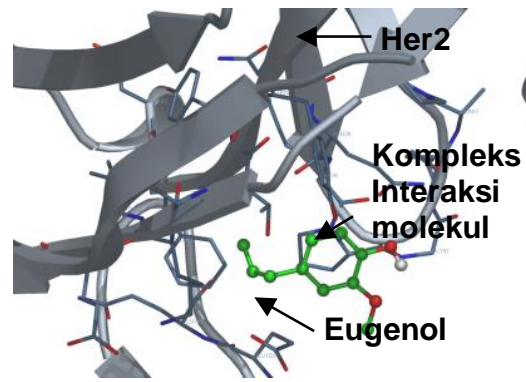

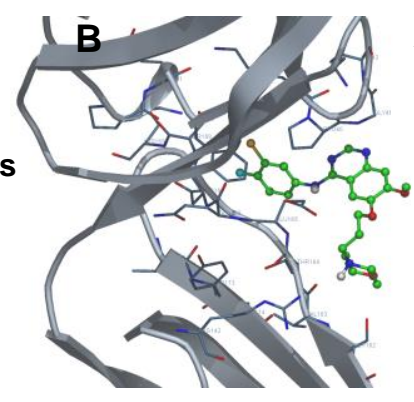

$\longleftarrow$ Her2

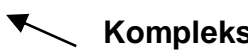

Interaksi molekul

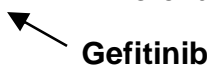

\section{Gambar 2 Gambar 3D Hasil Docking: A. Eugenol-Her-2, B. Gefitinib-Her-2}

Kompleks interaksi molekul yang merepresentasikan kemampuan ligand berikatan dengan reseptor target belum cukup untuk dapat memprediksikan efektivitas ikatan keduanya. Setidaknya ada 3 parameter yang dapat dilihat apakah interaksi keduanya cukup kuat dan memiliki aktivitas penghambatan. Tiga parameter tersebut antara lain yaitu: 1) Interaksi permukaan (interaction surface); 2) Besar nilai energi ikatan bebas (Free energy of binding); 3) Besar nilai konstanta inhibisi (Inhibition constant $=K i)$. Interaksi permukaan merupakan parameter yang menunjukkan luas area penambatan ligand dengan reseptor. Semakin besar nilai interaksi permukaan, maka semakin kuat ikatan kompleks ligand dan reseptor. Besar energi ikatan bebas merupakan besar energi yang dibutuhkan bagi kompleks molekul untuk berikatan. Hal ini sangat penting dalam menentukan kestabilan ikatan kompleks ligand reseptor. Semakin kecil energi ikatan bebas maka semakin stabil ikatan kompleks tersebut. Energi ikatan bebas yang kecil (semakin negatif), maka ketika kompleks tersebut terpisah untuk dapat melekat kembali tidak membutuhkan energi yang besar.

Nilai konstanta inhibisi merupakan nilai yang digunakan sebagai acuan dalam menentukan efektivitas penghambatan ligand terhadap aktivitas reseptor. Nilai konstanta inhibisi dikatakan semakin baik jika nilainya semakin kecil. Semakin kecil nilai Ki menunjukkan bahwa semakin kecil konsentrasi molekul yang dibutuhkan untuk dapat menghambat reseptor target. Tabel 1 berikut ini merupakan hasil pengukuran energi dari docking molekul eugenol, gefitinib, dan Her-2:

Tabel 1 Hasil Perbandingan Nilai Interaksi Permukaan Molekul, Jumlah Energi Ikatan Bebas dan Nilai Konstanta Inhibisi (Ki) pada Interaksi Eugenol-Her-2 dan Gefitinib-Her-2

\begin{tabular}{|cccc|}
\hline Kompleks Molekul & Interact. Surface & $\begin{array}{c}\text { Est. Free Energy of } \\
\text { Binding }\end{array}$ & $\begin{array}{c}\text { Est.Inhibition Constant } \\
\text { (Ki) }\end{array}$ \\
\hline 1,3,4-Eugenol-Her-2 & 411.564 & $-4.16 \mathrm{kcal} / \mathrm{mol}$ & $895.67 \mu \mathrm{M}$ \\
\hline Gefitinib-Her-2 & 668.342 & $-7.05 \mathrm{kcal} / \mathrm{mol}$ & $225.70 \mu \mathrm{M}$ \\
\hline
\end{tabular}


Di samping mengetahui gambaran kompleks ikatan ligand-reseptor antara eugenol-Her-2 dan gefitinib-Her-2, interaksi permukaan, energi ikatan bebas, serta nilai konstanta inhibisi, kita juga perlu mengetahui interaksi antar molekul pada kompleks ligandreseptor yang ditunjukkan pada $\mathrm{Hb}$ Plot berikut:

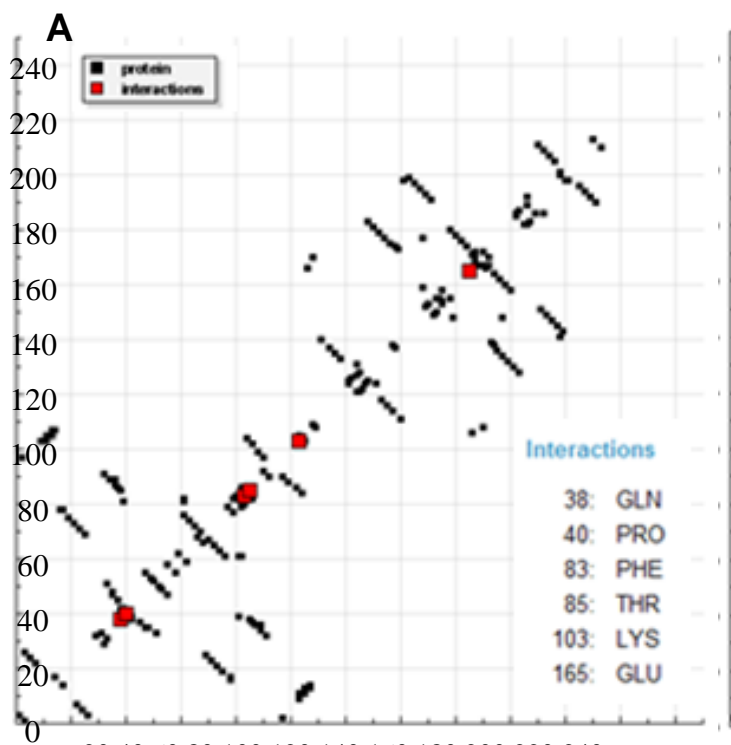

20406080100120140160180200220240

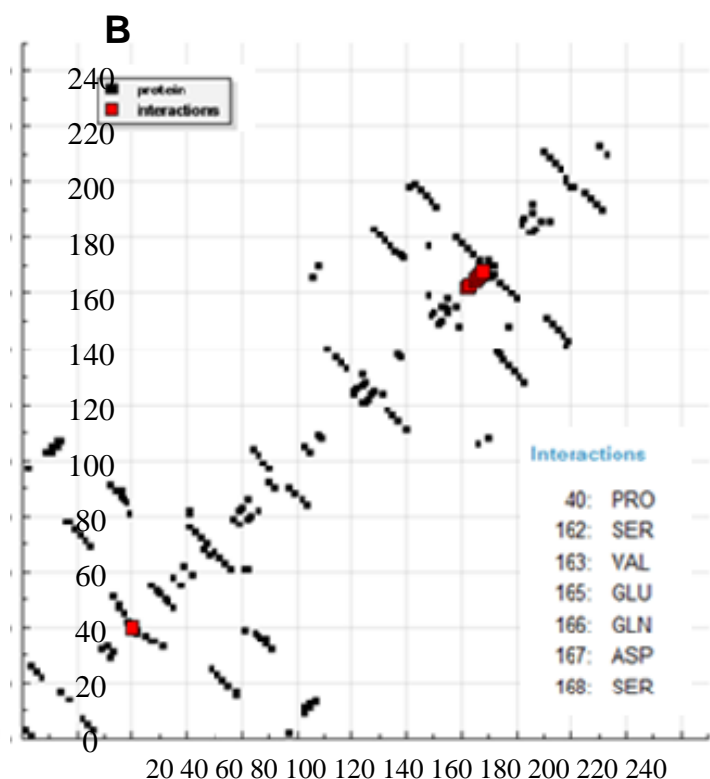

Gambar 3 Hasil Hb Plot yang Menunjukkan Interaksi Molekul Kedua Senyawa: A. Eugenol-Her-2, B. Gefitinib-Her-2

Interaksi antar molekul pada kompleks ligand reseptor terdiri dari sejumlah ikatan kimia dengan energi ikatan bebas masingmasing yang menunjukkan kestabilan ikatan. Tabel 2 berikut menunjukkan jenis-jenis ikatan kimia pada kompleks ligand reseptor beserta nilai energi ikatan bebas.
Tabel 2. Dekomposisi Energi Interaksi Antara Eugenol dengan Reseptor Her-2

\begin{tabular}{|cll|}
$\begin{array}{c}\text { Ikatan } \\
\text { Kovalen } \\
\text { Polar }\end{array}$ & \multicolumn{1}{c}{$\begin{array}{c}\text { Ikatan } \\
\text { Hidrofobik }\end{array}$} & \multicolumn{1}{c}{ Ikatan Lain } \\
$\begin{array}{c}\text { Glisin 38 } \\
\mathbf{( - 0 . 9 2 9 6 )}\end{array}$ & $\begin{array}{l}\text { Prolin 40 } \\
(-1.2416)\end{array}$ & $\begin{array}{l}\text { Lysin 103 } \\
(-0.4521)\end{array}$ \\
\cline { 2 - 3 } & $\begin{array}{l}\text { Phenylalanin 83 } \\
(-0.3434)\end{array}$ & $\begin{array}{l}\text { Glutamin 165 } \\
(-0.3799)\end{array}$ \\
\cline { 2 - 3 } & & Threonine \\
& & $(0.0399)$ \\
\hline
\end{tabular}

Tabel 3. Dekomposisi Energi Interaksi Antara Gefitinib dengan Reseptor Her-2

\begin{tabular}{|c|c|c|c|c|}
\hline $\begin{array}{l}\text { Ikatan } \\
\text { Hidrogen }\end{array}$ & Ikatan Halogen & $\begin{array}{c}\text { Ikatan Kovalen } \\
\text { Polar }\end{array}$ & $\begin{array}{l}\text { Ikatan } \\
\text { Hidrofobik }\end{array}$ & Ikatan Lain \\
\hline $\begin{array}{l}\text { Valin 163 } \\
(0.3885)\end{array}$ & $\begin{array}{c}\text { Asam Aspartat } 167 \\
(-0.7004)\end{array}$ & $\begin{array}{l}\text { Serin 162 } \\
(-0.2241)\end{array}$ & Prolin $40(0.2494)$ & $\begin{array}{c}\text { Glutamin } 165 \\
(-2.0834)\end{array}$ \\
\hline & $\begin{array}{l}\text { Glisin } 166 \\
(-0.5444)\end{array}$ & & & $\begin{array}{l}\text { Serin } 168 \\
(-0.4534)\end{array}$ \\
\hline
\end{tabular}

\section{PEMBAHASAN}

Suatu studi in silico dilakukan untuk mengetahui interaksi antara senyawa dari kandidat obat yang digunakan sebagai ligand dengan reseptor spesifik yang telah terbukti berkontribusi dalam prognosivitas dan progresivitas kanker. Dalam studi in silico ini eugenol merupakan suatu senyawa dari kandidat obat daun basil (Ocimum basilicum) yang telah terbukti memiliki aktivitas antikanker seperti efek sitotoksik, antiproliferatif dan pro-apoptosis di beberapa jenis kanker seperti kanker payudara, 
melanoma, kanker kolon dan NSCLC. Pada NSCLC, sinyal AKT aktif oleh adanya suatu komponen dalam rokok yaitu 4(methylnitrosamino)-1-(3pyridyl)-1-butanone (NNK) dan menyebabkan transformasi neuplastik. Her2 merupakan salah satu reseptor yang aktif pada kanker terutama dalam menginduksi proliferasi dan siklus sel pada jalur PI3K dan Akt (Ono et al., 2004). Sehingga dalam hal ini reseptor Her2 berperan sebagai target dari terapi. Beberapa obat kanker banyak dikembangkan dengan menghambat aktivitas reseptor Her2 seperti Traztuzumab (herceptin) dan gefitinib. Herceptin memiliki aktivitas dalam menghambat her2 sedangkan gefinitif memiliki aktivitas tyrosine kinase dan reseptor her2. Herceptin banyak digunakan pada kanker payudara (Devita et al., 2011), sedangkan gefitinib banyak terbukti aktif dan menyebabkan respon sensitive pada reseptor her2 di NSCLC (Soh et al., 2007; Hirata et al., 2005).

Berdasarkan hasil docking diketahui bahwa eugenol mampu berikatan dengan reseptor Her-2 dibuktikan dengan adanya interaksi permukaan sebesar 411. 564. Adanya interaksi permukaan menunjukkan bahwa eugenol mampu berikatan dengan reseptor $\mathrm{Her}$ 2 dengan luas interaksi sebesar 411.564. Nilai interaksi permukaan ini cukup besar dan hampir menyamai nilai interaksi gefitinib terhadap Her-2 sebesar 663.342. Dengan hasil docking ini kita dapat berasumsi bahwa ikatan eugenol memiliki reseptor target Her-2 pada NSCLC jika nantinya diberikan sebagai terapi.

Hal terpenting dalam kompleks molekul yaitu kestabilan ikatan antar molekul yang dapat ditandai dengan nilai energi ikatan bebas. Semakin kecil nilai ikatan bebas maka semakin sulit interaksi antar molekul dapat terlepas. Hal ini menunjukkan bahwa kompleks molekul akan semakin stabil. Nilai energi ikatan bebas kompleks eugenol dan Her-2 kecil yaitu $-4.66 \mathrm{kcal} / \mathrm{mol}$. Nilai energi ikatan bebas ini cukup baik terbukti hampir mendekati nilai energi ikatan bebas kompleks kontrol gefitinif dengan Her-2 yang besarnya $-7.05 \mathrm{kcal} / \mathrm{mol}$.

Berdasarkan hasil docking menggunakan docking server diketahui posisi interaksi antara ligand dan reseptor. Eugenol dapat membentuk ikatan polar dengan Her-2 pada asam amino glysin (38) dengan energi sebesar -0.9296. Eugenol dapat membentuk ikatan hidrofobik dengan Her-2 pada asam amino proline (40) dan phenilalanin (83) dengan energi sebesar 1.2416 dan -0.3434. Eugenol juga membentuk ikatan lain dengan Her-2 pada asam amino lysine (85), glutamine (103) dan threionin (165). Adanya ikatan kovalen polar pada kompleks molekul eugenol dan Her-2 menunjukkan bahwa kompleks ini memiliki ikatan yang kuat.

Aktivitas kompleks molekul yang diharapkan dari ikatan ini adalah penghambatan ligand terhadap reseptor yang ditentukan dari nilai konstanta inhibisi (Ki). Nilai konstanta inhibisi menunjukkan efektivitas molekul dalam menghambat reseptor target. Semakin kecil nilai Ki maka semakin efektif molekul dalam menghambat reseptor target. Berdasarkan hasil docking diketahui bahwa eugenol memiliki nilai Ki sebesar 895.67 $\mu \mathrm{M}$. Hasil ini menunjukkan bahwa eugenol memiliki aktivitas penghambatan terhadap Her-2 meskipun efektivitas gefitinib empat kali lebih baik $(225.70 \mu \mathrm{M})$.

Berdasarkan hasil studi ini diketahui bahwa eugenol mampu berikatan dengan reseptor Her-2 dengan stabil dan memiliki efek penghambatan pada reseptor tersebut walaupun ikatannya tidak sebaik gefitinib. Studi in silico ini membutuhkan studi lanjutan di laboratorium untuk mengetahui lebih jauh mengenai adanya interaksi antara eugenol dengan Her-2 serta mengetahui efek biologi yang disebabkan oleh interaksi tersebut terutama untuk menurunkan prognosivitas kanker $N S C L C$. Hal ini sangat penting sebagai studi awal diketahui potensi senyawa eugenol daun basil untuk menurunkan prognosivitas kanker melalui reseptor $\mathrm{Her}-2$ yang bekerja pada transduksi sinyal pertumbuhan di Akt pathway.

\section{SIMPULAN}

Secara in silico, senyawa eugenol daun basil (Ocimum basilicum L.) teruji mampu berikatan kuat dan stabil dengan reseptor Her2 serta memiliki kemampuan penghambatan terhadap reseptor tersebut. Hasil studi in silico ini menjadi gambaran awal untuk mengetahui kemampuan interaksi eugenol dengan Her-2 yang merupakan reseptor pada salah satu transduksi sinyal pertumbuhan sel kanker di NSCLC yang mengalami overekspresi. 


\section{DAFTAR PUSTAKA}

Addario, G. D., Fru, M., Reck, M., Baumann, P., Klepetko, W., Felip, E. 2010. Metastatic Non-Small-Cell Lung Cancer: ESMO Clinical Practice Guidelines for Diagnosis, Treatment and Follow up. Annals of Oncology. 21:116-119.

Agus, D. B., Bunn, P. A. Jr, Franklin, W., Garcia, M., Ozols, R. F. 2000. HER2/neu as a Therapeutic Target in NonSmall Cell Lung Cancer, Prostate Cancer, and Ovarian Cancer. Semin Oncol. 27: 53-63.

Albanell, J., Rojo, F., Averbuch, S., Feverreislova, A., JM, Mascaro., LoRusso, R., Rischin, P., Sauleda, D., Gee j., Nicholson, Baselga J. 2002. Pharmacodynamic Studies of the Epidermal Growth Factor Receptor Inhibitor ZD1839 in Skin from Cancer Patients: Histopathologic and Molecular Consequences of Receptor Inhibition. J Clin Oncol. 20: 110-124.

Al-Sharif. 2013. Eugenol Triggers Apoptosis in Breast Cancer Cell Through E2F1/Survivin Down Regulation. BMC Cancer. 13: 600.

Baselga, J. 2002. Why the Epidermal Growth Factor Receptor? The Rationale for Cancer Therapy. Oncologist. 7: 2-8.

Chen J, Bi H, Hou J, Zhang X, Zhang C, Yue L, Wen X, Liu D, Shi H, Yuan J, Liu J, Liu B. 2013. Atovastatin Overcomes Gefitinib Resistance in KRAS Mutant Human Non-Small Cell Lung Carcinoma Cells. Cell Death and Disease. 4: 814.

Devita, V. T., Lawrence, T. S., Rosenberg, S. A. 2011. Cancer-Principle and Practice Oncology. $9^{\text {th }}$ edition. Lippincott-Williams \& Walkins.

Fukuoka, M, Yano S, Giaccone G, Tamura T, Nakagawa K, Douillard JY, Nishiwaki Y, Vansteenkiste J, Kudoh S, Rischin D, Eek R, Horai T, Noda K, Takata I,
Smit E, Averbuch S, Macleod A, Feyereislova A, Dong RP, Baselga J. 2005. Multi-institutional Randomized Phase II Trial of Gefitinib for Previously Treated Patients with Advanced Non-Small Cell Lung Cancer. J Clin Oncol. 21: 2237-46.

Ghosh, R., Nadiminty, N., Fitzpatrickm J, E,m Alwort, W. L., Slaga, T. J, Kumar, A. P. 2005. Eugenol Causes Melanoma Growth Suppression through Inhibition of E2F1 Transcriptional Activity. The Journal of Biology Chemistry. 280 (7): 5812-5819.

Hirata, A., Hosoi, F., Miyagawa, M., Ueda, S., Naito, S., Fuiji, T., Kumano, M., Ono, M. 2005. HER2 Overexpression Increases Sensitivity to Gefitinib, an Epidermal Growth Factor Receptor Tyrosine Kinase Inhibitor, through Inhibition of HER2/HER3 Heterodimer. Cancer Res. 65: 42534260 .

Jaganathan, S. K., Mazumdar, A., Mondher, D., Mandal, M. 2011. Apoptotic Effect of Eugenol in Human Colon Cancer Cell Lines. Cell Biol. Int. 35: 607-615.

Keitha, S. M., Vincent, C., Schmit, J. P., Belanger, A. 2000. Essential Oil Composition of Ocimum basilicum L, O. grayissimum L. and O. Suave L. in the Republic of Guinea. Flavour Fragr J. 15: 339-341.

Lee, Seung-Joo., Umano, K., Shibamoto, T., Lee, Kwang-Geun. 2005. Identification of Volatile Components in Basil (Ocimum basilicum L.) and Thyme Leaves (Thymus vulgaris L.) and Their Antioxidant Properties. Food Chemistry. 91: 131-137.

Louie, G. V., Baiga, T. J., Bowman, M. E., Eduka, T. K., Taylor, J. H., Spassova, S. M., Pichersky, E., Noel, J. P. 2007. Strucutre and Reaction Mechanism of Basil Eugenol Synthase. PLOS ONE 2(10): e993. doi:10. 1371/journal.pone. 0000993 
Lynch, T.J., Bell, D.W., Sordella R, Gurubhagavatula S, Okimoto, R.A., Brannigan,B.W., Harris,P.L., Haserlat, S.M., Supko, J.G., Haluska, F.G., Louis,D.N., Christiani,D.C, Settleman J., Haber, D.A. 2004. Activating Mutations in the Epidermal Growth Factor Receptor Underlying Responsiveness of Non-Small CellLung Cancer to Gefitinib. $N$ Engl $J$ Med. 350: 2129-2139.

Ozkan, A. and Erdogan, A. 2012. Membran and DNA Damaging/Protective Effect of Eugenol, Eucalyptol, Terpinen-4-ol, and Camphor at Various Concentrations on Parental dan DrugResistant H1299 Cells. Turkish Journal of Biology. 37: 405-413.
Prenzel, N., Fischer, O. M., Streit, S., Hart, S., Ullrich, A. 2001. The Epidermal Growth Factor Receptor Family as a Central Element for Cellular Signal Transduction and Diversification. Endocr Relat Cancer. 8:11-31.

Soh, J., Toyooka, S., Ichihara, S. Fujiwara, Y., Hotta, K., Suehisa, H., Kobayasi, N., Acem K., Ace, M., Kiura, K., Date, H. 2007. Impact of HER2 and EGFR Gene Status on Gefitinib-treated Patients with Non-Small Cell Lung Cancer. Int. J. Cancer. 121: 1162-1167

Woodburn, J. R. 1999. The Epidermal Growth Factor Receptor and Its Inhibition in Cancer Therapy. Pharmacol Ther. 82: 241-550. 